\title{
Phytochemical Screening of Methanolic Extracts of Croton Mubango Müll Arg. and Indigofera Hendecaphlla Jacq. from the Province of Huambo, Angola
}

\author{
Armindo Paixão ${ }^{1 *}$, Justo dos Santos ${ }^{1}$, Cristovão Simoes ${ }^{1}$, Efigenia Camela ${ }^{1}$, Ruth Valentim ${ }^{2}$, Alexandrina \\ Caviendi ${ }^{3}$ and Luz María Sanchez ${ }^{4}$
}

${ }^{1}$ Faculty of Veterinary Medicine-Huambo, José Eduardo dos Santos University, Cuba

${ }_{2}^{2}$ Instituto de Investigação Veterinária-Huambo, Cuba

${ }^{3}$ Instituto Médio Agrário de Huambo, Cuba

${ }^{4}$ Centro Nacional de Sanidad Agropecuaria (CENSA), Cuba

Submission: April 24, 2019; Published: May 08, 2019

*Corresponding author: Armindo Paixão, Faculty of Veterinary Medicine-Huambo, José Eduardo dos Santos University, Angola, Cuba

\begin{abstract}
Summary
Plant species Croton mubango Müll Agr. and Indigofera hendecaphlla Jacq. they are traditionally used in various diseases in animals and humans in the province of Huambo, Angola. The objective of the present work was to determine the phytochemical composition of methanolic extracts of leaves of said species. The samples to be studied were collected in several places of Comuna Comandante Nzaji in the municipality of Huambo, in the rainy period. They were dried, milled and transferred to the National Center for Agricultural Health (Cuba) for phytochemical screening. The main groups found were primary and secondary aminos, free phenols, tannins, triterpenes and / or steroids and alkaloids. The primary and secondary amino compounds, free phenols, tannins and alkaloids were found in high amounts in the leaves of I. hendecaphlla and for C. mubango were found in this same amount in addition to amines the triterpenes and / or steroids since phenols and alkaloids They were presented in moderate quantity and tannins in a mild way. It is concluded that the methanolic extracts of the plants evaluated present secondary metabolites in moderate to high concentrations. The metabolites found in these two plant species are of biological and pharmacological interest for their possible therapeutic applications in both animals and humans.
\end{abstract}

Abstract

Croton mubango Müll Agr. and Indigofera hendecaphlla Jacq. especies of plant has been traditionally used in several desease of animal and human in Huambo Province, in Angola. The aim for this study was to determine the fitochemistry composition of metanolic extract of own sheet especies. The sample was obtained in several places of Comandante Zage District of Huambo City on rain season. They were exposed to dry at room temperature. Ground in a traditional method and transported to the National Health and Agropecuary Center to carry out phytochemical filtration. The main group found was primary and secondary amines, free fenol, tanins, triterpenes, steroids and alcaloids. The primary and secondary amines, free phenol, tanins, and alcaloids found in high quantities in sheet of Indigofera hendecaphlla, and the same quantities was found in Croton mubango Müll Agr. Beside the quantity of amines, triterpenes and steroids compounds, however, the phenol compound and alcaloids found in moderate quantity and tanine compound in low quantities. This study concludes that the metanolic extract of plants evaluated shows the secondary metabolites at high and moderate concentration. The metabolites found in this two especies of plants are of great biologic and pharmacologic interest for their therapeutic application in animals and human.

Keywords: Phytochemical screening; Croton mubango Müll Agr; Indigofera hendecaphlla Jacq; Fitochemistry Filtration

\section{Introduction}

In the search for new drugs, natural products stand out for their structural diversity, as they have privileged chemical structures, which evolved during their biosynthesis process [1].
These same authors affirm that plants are one of the main sources of biologically active molecules, for this reason, many of the Natural Products laboratories have included within their routines of separation, purification and identification of structures, various 
chemical and biological tests, with the purpose of selecting extracts and monitoring the phytochemical study. The objective of qualitative phytochemical screening is to know the chemical constituents of plant species or identify their presence in plants. When no chemical studies are available on the species of interest, the phytochemical analysis can identify the relevant secondary metabolite groups [2]. For the selection of plants to be studied, all botanical and chemotaxonomic information must be considered, in such a way that the probability of finding bioactive substances, whether unpublished or already described in the literature, is greater [3]. Angola is one of the regions rich in biodiversity in the world, it has more than 5000 species that are little known and within the possible sources of active substances are some endemic species in the country and in particular in the province of Huambo as Croton mubango Müll Arg. And Indigofera hendecaphlla Jacq.

The long years of war in the country provided a very strong knowledge in the use of medicinal plants by the shortage of synthetic medicines and in fact, revolutionized the traditional medicine that was used since then, whose knowledge is passed from parents to children. The species C. mubango is one of the plants that served as antimalarial and is still used to combat malaria, it is prepared in the form of stems for oral administration and leaves for baths. On the use of this plant as antimalarial, there is scientific reference as described by Mesia [4] in his study in the Democratic Republic of the Congo. In traditional medicine in Huambo I. hendecaphlla is widely used to treat wounds and respiratory problems in animals, in humans it has been used in communities for women after childbirth to involute the reproductive organs and restore the elasticity of the vaginal canal. Taking this background into account, this study aimed to identify the classes of secondary metabolites present in each extract of these two plants, in order to understand the traditional use of these plants in rural communities mainly and to be able to find new sources of substances active.

\section{Material and Methods}

The plants were collected in Angola in the months of February to March 2015 (rainy period), in the province of Huambo, Municipality of Huambo, in the comarca Comandante Nzaji in the neighborhood of Aviação, which is located in the central planalto. The central planalto is located in the agricultural zone 24 , of humid and dry climate, according to its altitude, with average temperature that oscillates between $19^{\circ} \mathrm{C}$ and $21^{\circ} \mathrm{C}$, the annual average precipitation varies of $1100 \mathrm{~mm}-1400 \mathrm{~mm}$; It has two predominant seasons (rainy and dry period), with fersialitic soils [5]. Phytochemical screening was carried out at the National Center for Agricultural Health (CENSA), Cuba. The collection and dehydration of the leaves of these plants were processed according to Cunha \& Zatta [6,7]. The leaves were collected in the morning, dried in the shade in the open air, then ground in a traditional pylon, stored in sealed and identified polyethylene bags and transported to Cuba. The phytochemical screening was used for the primary qualitative characterization of the secondary metabolites, according to the procedure of Rondina \& Coussio [8]. In the qualitative analysis, the system of crosses was used and the presence or absence of the secondary metabolites in the samples was specified according to the criteria of García [9]. Previously, standard compound solutions were used to control the reagents (Table 1).

Table 1: Specific / selective reactions for functional chemical groups.

\begin{tabular}{|c|c|c|}
\hline Metabolito & Essays & Control Solution \\
\hline Free phenols & $\mathrm{FeCl}_{3} 1-10 \%$ & Phenol 1\% \\
\hline Tannins & Gelatine 1\% & Tannic acid 1\% \\
\hline $\begin{array}{c}\text { Primary and } \\
\text { secondary aminos }\end{array}$ & Ninhidrina 0,2\% & L-Aspartic acid 1\% \\
\hline $\begin{array}{c}\text { Triterpenes and / or } \\
\text { steroids }\end{array}$ & Lieberman & Cholesterol 2\% \\
\hline Flavonoids & Shinoda & Quercetina 2\% \\
\hline Leucoantocianidines & Rosehein & D (+) Catechin 1\% \\
\hline $\begin{array}{c}\text { Cardiotonic } \\
\text { glycosides }\end{array}$ & Tuesday & $\begin{array}{c}\text { Digital 2\% (mass / } \\
\text { volume) }\end{array}$ \\
\hline Alkaloids & Dragendorff & Graminee 2\% Efedrina 2\% \\
\hline
\end{tabular}

\section{Results and Discussion}

Table 2: Phytochemical characterization of plants.

\begin{tabular}{|c|c|c|}
\hline Metabolitos & $\begin{array}{c}\text { I. hendecaphlla } \\
\text { (leaves) }\end{array}$ & C. mubango (leaves) \\
\hline Amines*** & +++ & +++ \\
\hline Phenols & +++ & + \\
\hline Tannins & +++ & +++ \\
\hline $\begin{array}{c}\text { Triterpenes and } \\
\text { Steroids }\end{array}$ & ++ & - \\
\hline Quinonas & - & ++ \\
\hline Alkaloids & +++ & - \\
\hline Flavonoids & - & - \\
\hline Leucoantocianidines & - & - \\
\hline Lactonic rings & - & \\
\hline
\end{tabular}

+++ : High presence

++: Moderate presence

+: Mild presence

-: Absence

***: Amines (primary and secondary)

Table 2 shows the primary phytochemical characterization of the methanolic extracts of the two species of plants collected in the rainy period. The main groups found were the primary and secondary amines, free phenols, tannins, triterpenes and / or steroids and alkaloids, while the flavonoids, lactone rings, quinones and leucoanthocyanidins were not detected in the screening performed. The families of secondary metabolites determined in the extracts studied are recognized as carriers of important biological actions. Thus, it can be said that the use of these plants in traditional medicine is related to the presence of these chemical elements, since several therapeutic properties of 
these metabolites have been described, such as tannins that have healing and antiseptic activity (antibacterial and antifungal) [10], vasoconstrictor, antidiarrheal [11] among others. It has been described for therapeutic properties alkaloids as antimicrobials, stimulant of the central nervous system and as an analgesic [12]. Anti-inflammatory, antimicrobial, antimalarial, anticarcinogenic and analgesic activities are described for triterpenes [13].

\section{Conclusion}

The two species of plants studied can be a source of biologically active substances for the treatment of various diseases, since they have metabolites with pharmacological activity that are described as relevant and for which traditional use can be based.

\section{References}

1. Feher M, Schmidt JM (2003) Property distributions: differences between drugs, natural products and molecules from combinatorial chemistry. J Chem Inf Computer Sci 43(1): 218-227.

2. Simões CMO (2001) Pharmacognosy: from the plant to the medication. ( $3^{\text {rd }}$ edn), Porto Alegre (Eds.), from the UFSC.

3. Clardy J, Walsh C (2004) Lessons from natural molecules. Nature 432 829-837.

4. Mesia GK, Tona GL, Penge O, Lusakibanza M, Nanga TM, et al. (2005) Antimalarial activities and toxicities of three plants used as traditional remedies for malaria in the Democratic Republic of Congo: Croton mubango, Nauclea pobeguinii and Pyrenacantha staudtii. Ann Trop Med Parasitol 99(4): 345-357.
5. Diniz AC (2006) Mesological characteristics of Angola. IPAD, ( $2^{\text {nd }}$ edn), Lisbon.

6. Cunha AP, Silva AP, Roque OR (2006) Plants and plant products in herbal medicine. Colouste Gulbenkian Foundation. Education and Scholarship Service. Lisbon - Portugal ( $\left.2^{\text {nd }} e d n\right)$, p. 21-54.

7. Zatta M (2007) The pharmacy of nature. (20 ${ }^{\text {th }}$ edn), São Paulo: Paulinas, series II: 141

8. Rondina RVD, Coussio JD (1969) Phytochemical study of medicinal plants (I). Revista de Investigaciones Agropecuarias. Series 2 Biology and Plant Production 6(22): 351-366.

9. García DE (2003) Evaluation of the main factors that influence the phytochemical composition of Morus alba (Linn.). Thesis submitted in option to the master's degree in Pasture and Fodder. EEPF "Indian Hatuey". Matanzas, Cuba, p. 97.

10. Fennema OR (2010) Fennema food chemistry. ( $4^{\text {th }}$ edn), Porto Alegre: Artmed. Brazil.

11. Kuklinski C (2005) Pharmacognosy: Study of medications and drugs of natural origin. In: Navarro-Schmidt. Chemical, biological, and pharmacological study of the species of Allamanda blanchetti and Allamanda schottii for obtaining bioactile molecular weight and molecular fractions of therapeutic potential. PhD thesis UFSC. p. 5.

12. Anwar F, Latir S, Ashraf M, Gilan A (2007) Moringa oleifera to Food Plant with Multiple Medicinal Uses. Journal of Phytotherapy Research 21: $17-25$.

13. Dzubak P, Hajduch M, Vydra D, Hustova A, Kvasnica M, et al. (2006) Pharmacological activities of natural triterpenoids and their therapeutic implications. Previous review: Nat Prod Rep 22: 487.

\section{Your next submission with Juniper Publishers will reach you the below assets}

- Quality Editorial service

- Swift Peer Review

- Reprints availability

- E-prints Service

- Manuscript Podcast for convenient understanding

- Global attainment for your research

- Manuscript accessibility in different formats

( Pdf, E-pub, Full Text, Audio)

- Unceasing customer service

Track the below URL for one-step submission https://juniperpublishers.com/online-submission.php 